American Journal of Agricultural and Biological Sciences 5 (3): 357-362, 2010

ISSN 1557-4989

(C) 2010 Science Publications

\title{
Vegetation Analysis of Sutan-Chay Basin in Arasbaran
}

\author{
${ }^{1}$ T. Ebrahimi Gajoti, ${ }^{1}$ V. Haciyev, ${ }^{2}$ A. Javanshir, ${ }^{3}$ H. Nosrati, \\ ${ }^{4}$ A. Razban Haghighi, ${ }^{5}$ A. Eimanifar and ${ }^{6}$ N. Stewart, Jr. \\ ${ }^{1}$ Institute for Botany of National Academy of Azarbaijan, \\ Department of Botany, Baku, Azerbaijan \\ ${ }^{2}$ Department of Agriculture, Agronomy, \\ ${ }^{3}$ Department of Systematic, \\ University of Tabriz, Iran \\ ${ }^{4}$ Research Centre for Agriculture and Natural Resources, \\ Department of Physiology and Genetic, Tabriz, Iran \\ ${ }^{5}$ Institute of Pharmacy and Molecular Biotechnology, Department of Biology, \\ Im Neuenheimer Feld 364, D-69120 Heidelberg, Germany \\ ${ }^{6}$ Department of Plant Sciences, University of Tennessee, Knoxville, TN, USA
}

\begin{abstract}
Problem statement: Plants associations differ in relation to environmental gradients. Therefore, it is necessary to study the interaction between ecological factors and vegetation. Approach: In this study vegetation and flora of Sutan-Chay Basin in Arasbaran was investigated using Braun Blanquet method as physiognomic floristic. Sampling of soil and vegetation was carried out by selecting areas with homogenous plant compositions. The surface area of releves was determined using Nested Plot method to obtain the Minimal area. Classification of releves was conducted based on the presence and cover percentage of species using cluster analysis and Jaccard index similarity. CCA was used to determine the relationship between the groups and ecological factors and the most important factors in separating the groups and distribution of the species. The classification of releves based on Jaccard's similarity coefficient and cluster analysis showed 6 different groups. Results: Dendrogram of cluster analysis based on these methods showed six associations: Astragaleto aureus-Thymetum kotschyanus, Poeto bulbosa-Festucetum ovina, Carpinetum betulus 'Quercetum macranthera, Paliuretum spina-christii, Juniperetum foetidissima. Canonical Correspondence Analysis (CCA) was used to determine the most important environmental factors on plant groups. This method of multivariate showed that $\mathrm{pH}$, TNV\%, soil texture, clay percentage, altitude and aspects had higher effect on separation of plant groups, which had correlation with axes 1 and 2 of ordination. Conclusion: Among the environmental factors the altitude has most important effect on plants distribution. With understanding of relationship between ecological factors and plant associations in a given area, it is possible to apply the obtained results in management and revival of forestland and rangeland.
\end{abstract}

Key words: Vegetation, canonical correspondence analysis, Arasbaran, ordination, environmental factors, classification

\section{INTRODUCTION}

Variation in vegetation composition and the distribution of the species are only understandable within a community ecological framework taking into account rhyzosphere characteristics (Tansley, 1935; Waring, 1988). For example, a study on relationship between soil salinity and species diversity in Qom
Province, Iran showed low level of species diversity due to decrease in uptaking nutrients and seed germination (Jafari et al., 2003). In vegetation analysis along irrigation and drain canals in damietta province, Egypt using Twinspan classification (two ways indicator species analysis) and Detrended Correspondence Analysis (DCA) ordination techniques revealed four groups of vegetation and indicated the

Corresponding Author: A. Eimanifar, Institute of Pharmacy and Molecular Biotechnology, Department of Biology, Im Neuenheimer Feld 364, D-69120 Heidelberg, Germany 
most important factors affecting on vegetation (Mashaly et al., 2001).

Based on CCA analysis of aquatic vegetation in the northeastern Nile Delta in Egypt, electrical conductivity, calcium, sodium, potassium, magnesium, total nitrogen, chlorides and bicarbonates had important effects on identifying the plants groupsand showed that the plants groups were correlated with the first and second ordination axes (Abu Ziada et al., 2008). Study on the vegetation of coast and salt marsh in Northern West Greenland using CCA and Twinspan methods showed that amount of soil nitrogen was correlated with the Class of Honckenyo Elymetea arenariae (Lepping and Daniels, 2007).

CCA and partial CCA methods have also been used in studying of changing plant species resulted from disturbance by human activities, environmental factors and their interactions in rain forests of Polynesian Islands (Franklin et al., 2006). Studies in Arasbaran forests emphasized the importance of quantitative and qualitative analysis, environmental issues resulting from human activities and revival structure of young stands (Alijanpour and Mahmoudzadeh, 2007).

The main purpose of the research reported here was to investigate the relationship between environmental characteristics with plant species to determine the most important factors affecting the separation of plant associations Sutan-Chay Basin in Arasbaran, Iran. The other objective was to determine the soil characteristics that are indicator of character species.

\section{MATERIALS AND METHODS}

In this study vegetation and flora of Cutan-Chai Basin in Arasbaran region was investigated using Braun Blanquet (1932) method. The study area is located within Arasbaran Protected region. The altitude ranges from 450-2400 $\mathrm{m}$ covering 13,335 ha. Vegetation of plots in the area were studied in 3 years during 20072009 using Flora Iranica (Rechinger, 1986), Flora of Turkey (Davis, 1982), Flora of Iran (Asadi, 1988), Flora of Russia (Komarov and Shishkin, 1972) and Flora of Palestine (Zohary and Feindbrun-Dothan, 1972). The area under study has annual rainfall ranges from 190-540 mm with mean value of about $378 \mathrm{~mm}$ and is classified in de Martonne method as semi-arid, cold.

The soil samples were collected at a depth of 0-60 $\mathrm{cm}$ then dried, thoroughly mixed and passed through a $2 \mathrm{~mm}$ sieve to be ready for physical and chemical analyses. Location altitude and aspect were assessed and 60 releves were established in the area for sampling of vegetation.
Soil texture was determined using sieve method for coarse soil and Bouyoucous hydrometer for the heavy soil samples. Moisture content, porosity and water holding capacity were measured using according to method (Piper, 1947). Organic carbon was determined using rapid titration method (Black, 1979). Soil salinity (EC) and soil reaction $(\mathrm{pH})$ were estimated in 1:5 soilwater extract using the conductivity and $\mathrm{pH}$ meters, respectively. The concentration of elements such as $\mathrm{N}$, $\mathrm{K}$ and $\mathrm{P}$ were estimated using a flame photometer.

For each vegetation type, a minimal area was obtained. Establishment of associated individuals or releves was carried out as selective in the areas with homogenous vegetation (Cain et al., 1959). The list of species in each releve was entered into a table, in which each species are presented with two numbers as Abundance dominance index and Sociability index (Kuchler and Zonneveld, 1988). The similarity between releves was compared as pairwise using Jaccard similarity coefficient (Jaccard, 1928). Cluster analysis among releves was conducted based minimum variation using Ward (1963). Association recognition was done based on two factors: fidelity and constancy (Braun Blanquet, 1932).

CCA was used to determine the relationship between the groups and ecological factors and the most important factors in separating the groups and distribution of the species. CCA is a direct ordination which its diagram gives changes of environmental and species data. In CCA regression and correlation were used (Ter Braak and Prentice, 1988).

\section{RESULTS}

A total number of 303 species were recorded in the study area encompassing 211 genera from 60 families including 245 dicots and 47 monocots, 6 ferns and 5 gymnosperms. Lamiaceae (36 species), Poaceae (33 species), Asteraceae (33 species), Rosaceae (29 species), Papilionaceae (21 species), Brassicaceae (12 species), Caryophyllaceae (11 species) and Liliaceae (10 species) are represented collectively by 185 species or about $61 \%$ of the total number of the recorded species.

The number and percentage of the biological forms recognized in the area were Therophyte (69 species, 23\%), Geophyte (23 species, 8\%), Hemicryptophyte (142 species, 46\%), Chamephyte (12 species, 4\%) and Phanerophyte 57 species, 19\%). Based on Whittaker physiognomy classification we recognized four formations (forest, scrub, dwarf, grassland) and 17 vegetation types based on the dominant species. 
The classification of releves based on Jaccard's similarity coefficient and cluster analysis showed 6 different groups, of which 4 groups belong forestland (forest and scrub) and two were of rangelands (Fig. 1). Based on different intervals, respectively 5-7 plant groups were identified using root of $1 / 2$ of releves number (5.4), which was equal to 6 of plant associations (Fig. 3): Astragaleto aureus-Thymetum kotschyanus, Poeto bulbosa-Festucetum ovina, Carpinetum betulus'Quercetum macranthera, Paliuretum spina-christii, Juniperetum foetidissima.

The correlation among environmental variables and axes 1, 2 and 3 are shown in Table 1. According to the results of Mont Carlo Test shown in Table 2, Eigenvalues of axes 1, 2 and 3 of CCA are 0.703, 0.476 and 0.250 . As seen, axis 1 value indicates the highest change of vegetation structure.

The results of the Monte Carlo test (Table 3) regarding correlation between plant species and environmental factors show that correlation between variables and axis 1 was significant $(p=0.01)$ and correlation between plant species and variants at axes 13 were $0.975,0.902,0.899$ respectively.

The CCA ordination was used to find out the most important environmental factors on the separation of the plant groups. In Fig. 2 the distance between points representing releves or types or associations shows the levels of differences. According to Fig. 2, altitude and silt had direct correlation with both species of constituent Astragaleto aureus-Thymetum kotschyanus association and species of constituent Poeto bulbosaFestucetum ovina association.

Table 1: Inter-set correlations for 14 factors

Correlations

\begin{tabular}{lrrr} 
Variable & Axis 1 & Axis 2 & Axis 3 \\
\hline q1( S.P) & 0.083 & 0.320 & -0.036 \\
q2 (EC) & -0.079 & -0.220 & -0.315 \\
q3(pH) & -0.800 & 0.134 & -0.214 \\
q4(T.N.V) & -0.553 & -0.318 & -0.422 \\
q5(N) & 0.390 & 0.331 & 0.142 \\
q6(C) & 0.291 & 0.314 & 0.091 \\
q7(P) & 0.067 & 0.085 & -0.079 \\
q8(K) & -0.149 & 0.053 & -0.100 \\
q9(Soil texture) & -0.351 & 0.424 & -0.010 \\
q10(Clay) & -0.482 & 0.270 & 0.023 \\
q11(Silt) & 0.458 & -0.211 & 0.209 \\
q12(Sand) & 0.151 & -0.112 & -0.125 \\
q13(Alt) & 0.895 & 0.307 & -0.132 \\
q14(Aspect) & -0.054 & 0.340 & 0.076 \\
\hline
\end{tabular}

Note: Obtain joint plots or biplots by selecting GRAPH, then requesting "Joint Plots" from the GRAPH menu

Table 2: Monte Carlo test results-eigenvalues

Randomized data

Real data Monte Carlo test 99runs

\begin{tabular}{llllll} 
Axis & Eigen value & Mean & Minimum & Maximum & $\mathrm{p}$ \\
\hline 1 & 0.703 & 0.339 & 0.261 & 0.478 & 0.01 \\
2 & 0.476 & 0.268 & 0.208 & 0.397 & 0.01 \\
3 & 0.250 & 0.222 & 0.182 & 0.295 & 0.09 \\
\hline
\end{tabular}

p: Proportion of randomized runs with eigenvalue greater than or equal to the observed eigenvalue i.e., $\mathrm{p}=(1+$ no. permutations $\geq$ observed $) /(1+$ no. permutations $)$

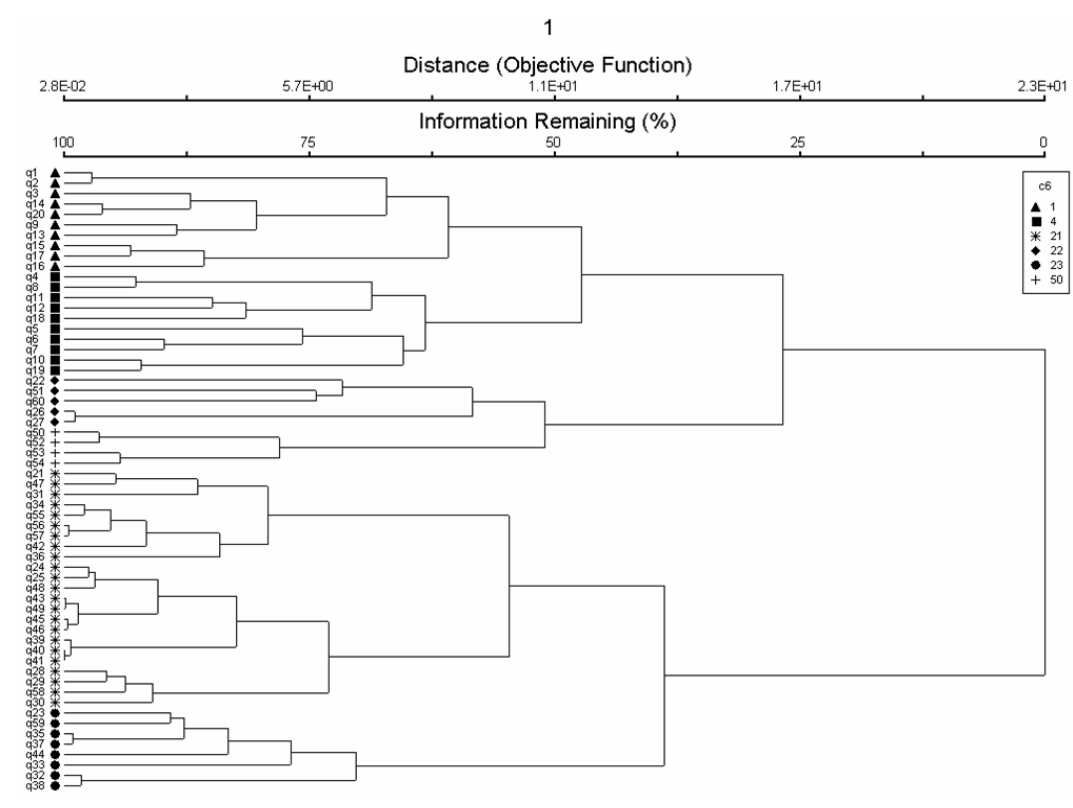

Fig. 1: Dendrogram showing similarities among groups based on Jaccard similarity coefficient. Six different groups were recognized. \: Astragaleto aureus-Thymetum kotschyanus; $\mathbf{\square}$ : Poeto bulbosa-Festucetum ovina; Juniperetum foetidissima; •: Quercetum macranthera; +: Paliuretum spina, christii; *: Carpinetum betulus 


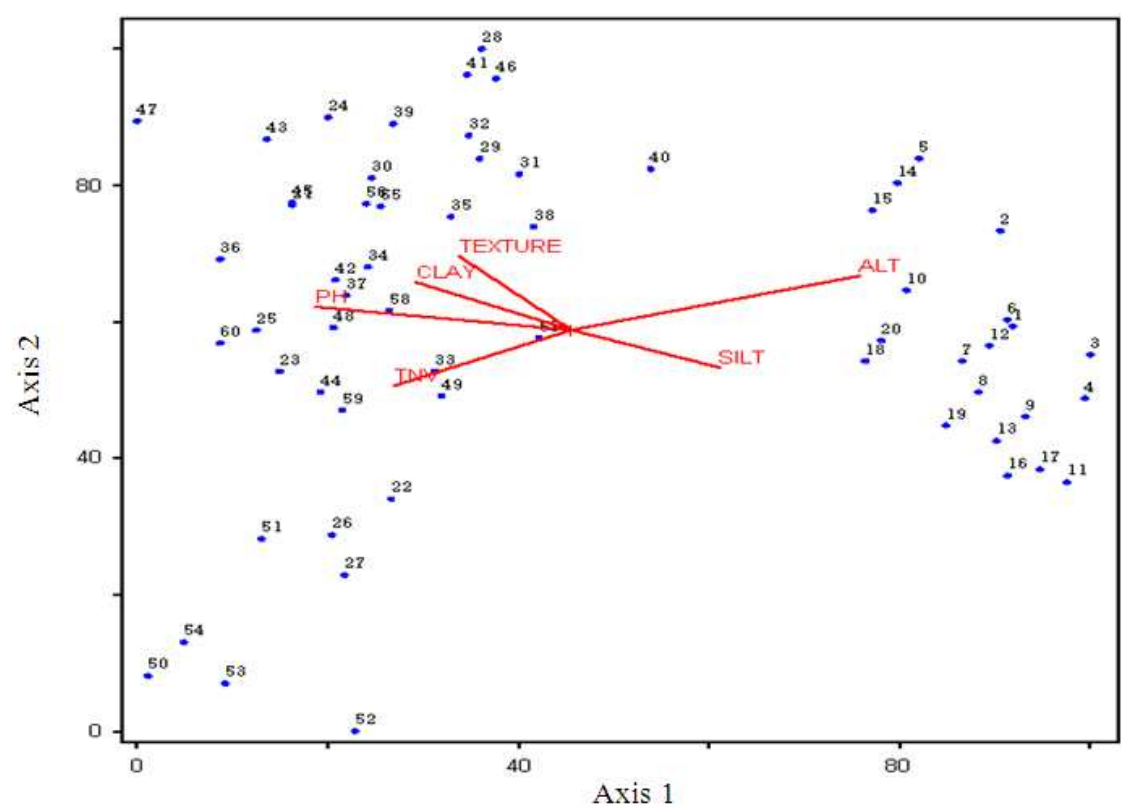

Fig. 2: Relationship between environmental factors and different releves based on axes 1 and 2

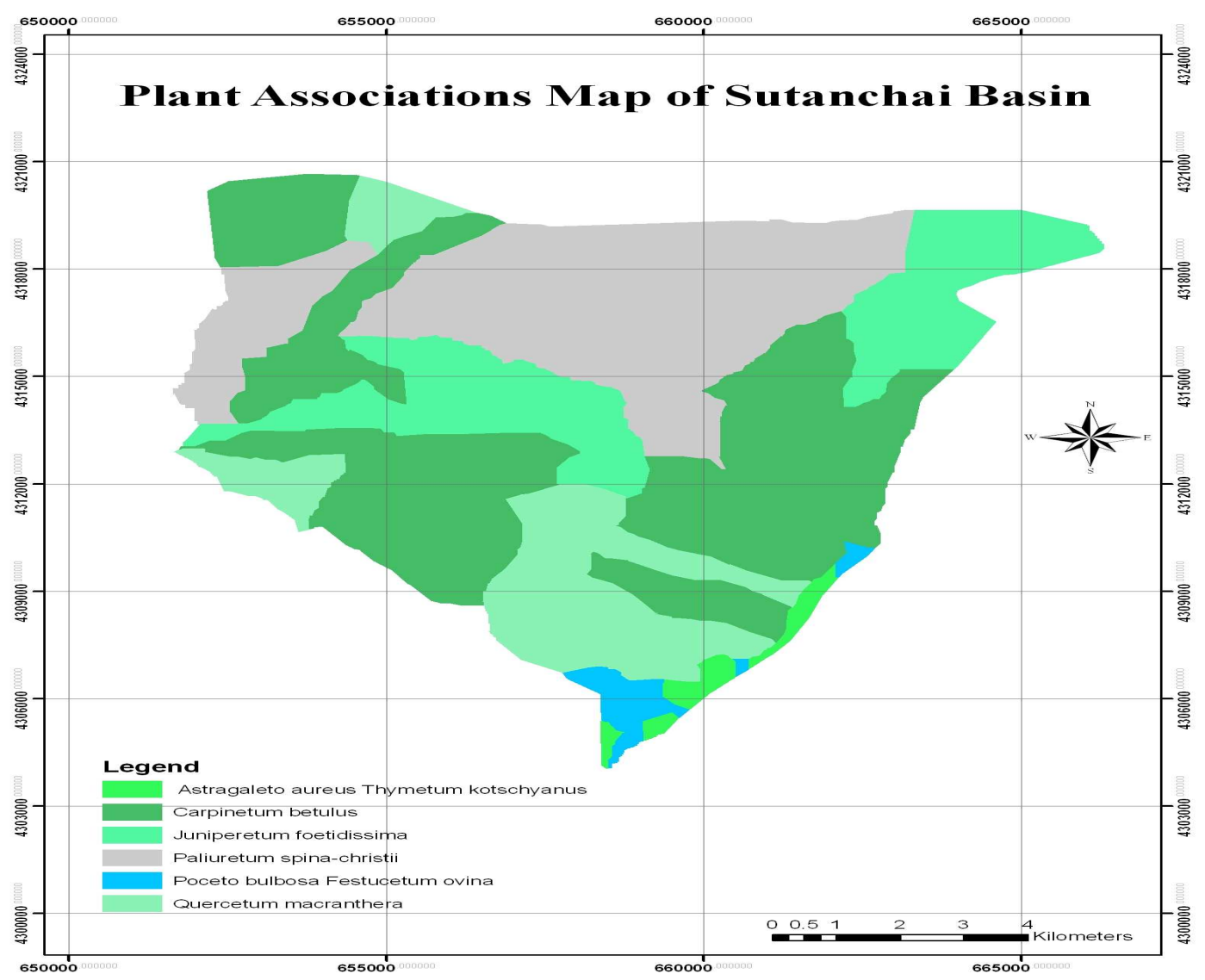

Fig. 3: Plant associations of the studied region, Arasbaran (Sutan-Chay) 
Am. J. Agri. \& Biol. Sci., 5 (3): 357-362, 2010

Table 3: Monte Carlo test results: Species-environment correlations Randomized data

\begin{tabular}{|c|c|c|c|c|c|}
\hline \multicolumn{2}{|c|}{ Real data } & \multicolumn{4}{|c|}{ Monte Carlo test 99runs } \\
\hline Axis & Spp-Envt Corr & Mean & Minimum & Maximum & $\mathrm{p}$ \\
\hline 1 & 0.975 & 0.801 & 0.7 & 0.968 & 0.01 \\
\hline 2 & 0.902 & 0.798 & 0.712 & 0.959 & 0.03 \\
\hline 3 & 0.899 & 0.827 & 0.721 & 0.935 & 0.06 \\
\hline
\end{tabular}

In Fig. 2 the altitude vector is longer than that of others and its angle with axis 1 is smaller than others and its correlation with axis 1 is highest (Table 1; 0.8950). Soil acidity (-0.800), TNV (-0.553), percentage of clay $(-0.482)$ and \% silt $(0.458)$ had higher correlation with axis 1 , respectively. On axis 2 , soil texture and aspect respectively with 0.424 and 0.340 correlations values had the most important affect.

\section{DISCUSSION}

The high taxa richness ( 303 species) in a small area (about 13,000 ha) indicates the diversity in microclimate and soil characters, according to Magurran (1988). Our data showed that environmental factors play important role on distribution of plant species. Of these factors, characteristics of soil e.g., texture, percentage of clay and silts, acidity and TNV\%, as well as ecological factors e.g., aspect and altitude had the most important impact on plant associations.

The study area has phytoclima of hemicryptophytic since it has $46.86 \%$ of species belonging to hemicryptophytes (Tivy, 1982). This shows that the climate of the area was moderate and semi-arid. Although the majority of the species in the area belongs to hemicryptophytes, in terms of physiognomy, phanerphytes were of dominant statue. The biological forms of the species are corresponding with classification (Raunkaier, 1934).

With the understanding of relationship between ecological factors and vegetations in a given area, it is possible to apply the obtained results in management and revival of forestland and rangeland. Those releves or species with shorter vertical distance with environmental factors vectors show that they have strong relationship with these factors (Ter Braak, 1987). Mont Carlo test results showed that environmental factors are significantly correlated with plant species (Table 3 ).

Our results show that there is a specific relationship between ecological factors and separation of plant groups and that these factors had effects on the distribution of associations in the area.

Assessment of the effects of environmental factors on composition of plant vegetations and separations of associations have been conducted using Twinspan
'DCA and CCA methods in other areas across the world (Hejcmanova-Nezerkova and Hejcman, 2006; Kim and Kil, 1997; Chou et al., 2000).

These two rangeland associations (Astragaleto aureus-Thymetum kotschyanus and Poeto bulbosaFestucetum ovina) are negatively correlated with soil texture, clay, acidity and TNV\%. If soils change from sandy-loam to loamy-sand and sandy-clay-loam and with increasing the values of above-mentioned factors, the number of character species of these associations decreases. Moreover, increasing of soil silt percentage and intermediate texture has made the presence of these associations' species increase.

The forest associations of Carpinetum betulus and Quercetum macranthera are directly and positively correlated with ecological factors such as soil texture, clay, acidity and $\mathrm{TNV} \%$. This means that the density, presence and distribution of their character species increase with increasing of these factors. Conversely, the density, presence and distribution of character species of forest associations of Carpinetum betulus and Quercetum macranthera showed negative correlation with altitude and silt factors and these associations prefer intermediate soil texture such as sandy loam and loamy sand.

The altitude vector was longer than the other sand its angle with axis 1 is smaller, indicating that altitude has most important effect on plants distribution (Table 1).

All releves forming of Paliuretum spina-christii and number of its character species had positive and direct correlation with soil acidity, this has resulted from the degradation of organic materials. The amount of clay increases in lowlands due to accumulations of clay resulted from erosion. In Paliuretum spina-christii association the members of all releves except releve number 52 showed positive and direct correlation with clay. The members of Paliuretum spina-christii association showed negative correlation with altitude and silt. In other words, this association and its species were distributed in low altitude compared to the other associations in the region.

The character species of Juniperetum foetidissima had positive and direct correlation with clay, TNV\% and acidity of soil, so that by increasing of these factors, its species distributions increase.

\section{CONCLUSION}

Our results showed that $\mathrm{pH}, \mathrm{TNV} \%$, soil texture, clay percentage, altitude and aspects had higher effect on separation of plant associations. Among the environmental factors the altitude has most important effect on plants distribution.

In the study area, forest associations in the lower altitude of $1800 \mathrm{~m}$ in height and pasture associations above $1800 \mathrm{~m}$ were observed. With understanding of relationship between ecological factors and plant 
associations in a given area, it is possible to apply the obtained results in management and revival of forestland and rangeland.

\section{ACKNOWLEDGMENT}

This research was supported by Research Center of Agricultural and Natural Resources of East Azarbaijan, Tabriz, Iran.

\section{REFERENCES}

Abu Ziada, M.E., I.A. Mashaly and M. Torky, 2008. Ecological studies on the aquatic vegetation in North East Nile delta. Egypt Int. J. Bot., 4: 151-163. DOI: 10.3923/ijb.2008.151.163

Alijanpour, A. and A. Mahmoudzadeh, 2007. Investigation and comparison of natural regeneration structure of forest stands in protected and non-rotected areas in Arasbaran. Pak. J. Biol. Sci., 10: 1697-1702. PMID: 19086520

Asadi, M., 1988. Plant species of Arasbaran protected Region, Northwest of Iran. J. Bot., 4: 1-59.

Black, C.A., 1979. Methods of soil analysis. Am. Soc. Agron., 2: 771-772.

Braun Blanquet, J., 1932. Plant Sociology. 1st Edn., Translated by G.D. Fuller and H.S. Conard, McGraw-Hill Book Company, Inc., New York, ISBN: 3-87429-208-8, pp: 439.

Cain, S.A. and G.M. de Olivieria Castro, 1959. Manual of Vegetation Analysis. 1st Edn., Harper and Brothers Publishers, New York, pp: 325.

Chou, C.H., T.Y. Chen, C.C. Liao and C.I. Peng, 2000. Long-term ecological research in the Yuanyang Lake Forest ecosystem I. Vegetation composition and analysis-bot. Bull. Acad. Sin., 41: 61-72.

Davis, P.H., 1982. Flora of Turkey. 1st Edn., University of Edinburgh, Scotland, UK., pp: 947.

Franklin, J., S.K. Wiser, D.R. Drake, L.E. Burrows and W.R. Sykes, 2006. Environment, disturbance history and rain forest composition across the islands of Tonga, Western Polynesia. J. Vegetat. Sci., 17: 233-244. DOI: 10.1111/j.16541103.2006.tb02442.x

Hejcmanova-Nezerkova, P. and M. Hejcman, 2006. A Canonical Correspondence Analysis (CCA) of the vegetation-environment relationships in Sudanese savannah, Senegal. South Afr. J. Bot., 72: 256-262. DOI: 10.1016/j.sajb.2005.09.002

Jaccard, P., 1928. Die statistisch-floristische method als grundlage der pflanzensoziologie. Abderhalden, Handb. Biol. Arbeitsmeth., 11: 165-202.

Jafari, M., M.A. Zare Chahouki, A. Tavili and H. Azarnivand, 2003. Soil-vegetation relationships in Hoz-e-Soltan region of Qom province, Iran. Pak. J. Nutr., 2: 329-334. DOI: 10.3923/pjn.2003.329.334
Kim, C.H. and B.S. Kil, 1997. Canonical Correspondence Analysis (CCA) on the forest vegetation of Mt. Togyu National Park, Korea. Korea J. Ecol., 20: 125-132.

Komarov, V.L. and B.K. Shishkin, 1972. Flora of USSR. 1st Edn., Ipst and Keter Press, Jerusalem, pp: 523.

Kuchler, A.W. and T.S. Zonneveld, 1988. Vegetation Mapping. 1st Edn., The Ronald Press Company, New York, ISBN: 90-6193-191-6, pp: 635.

Lepping, O. and J.A. Daniels, 2007. Phytosociology of beach and salt marsh vegetation in Northern West Greenland. Polarforschung, 76: 95-108.

Mashaly, I.A., E.F. El-Halawany and G. Omar, 2001. Vegetation analysis along irrigation and drain canals in Damietta Province, Egypt. J. Biol. Sci., 1:1183-1189.

Magurran, A.E., 1988. Ecological Diversity and its Measurement. 1st Edn., Princeton University Press, Princeton, NJ., ISBN: 10: 0691084912, pp: 192.

Piper, C.S., 1947. Soil and Plant Analysis. 1st Edn., University of Adelaide, Australia, pp: 368.

Raunkaier, C., 1934. The Life Forms of Plants and Statistical Plant Geography. 1st Edn., Clarendon Press, Oxford, pp: 632.

Rechinger, K.H., 1986. Flora Iranica. 1st Edn., Academische Druck-u, Graz, pp: 234.

Tansley, A.G., 1935. The use and abuse of Vegetational concepts and terms: Ecology, 16: 284-307. DOI: 10.2307/1930070

Ter Braak, C.J.F. and I.C. Prentice, 1988. A theory of gradient analysis. Adv. Ecol. Res., 18: 271-317. DOI: 10.1016/S0065-2504(08)60183-X

Ter Braak, C.J.F., 1987. The analysis of vegetationenvironment relationships by canonical correspondence analysis. Vegetation, 64: 69-77.

Tivy, J., 1982. Biogeography: A Study of Plants in the Ecosphere. 2nd Edn., Longman, London, pp: 460.

Ward, J.H., 1963. Hierarchical grouping to optimize an objective function. Am. Stat. Assoc. J., 58: 236-44. DOI: $10.1234 / 12345678$

Waring, R.H., 1988. Ecosystems: Fluxes of Matter and Energy. In: Ecological Concepts: The Contribution of Ecology to an Understanding of the Natural Word, Cherrett, J.M. (Ed.). British Ecological Society/Blackwell Scientific Publications, Oxford, pp: 17-41.

Zohary, M. and N. Feindbrun-Dothan, 1972. Flora Palaestina. 1st Edn., The Israel Academy of Sciences and Humanities, Jerusalem, pp: 364. 